\title{
Model guided inquiry, student team achievement division dan kemampuan penalaran matematis siswa
}

\section{Resti Mardiana Lestari, Rully Charitas Indra Prahmana ${ }^{1}$}

\begin{abstract}
Abstrak: Penelitian ini bertujuan untuk mengetahui perbedaan pengaruh penerapan model Guided Inquiry dengan model Student Teams Achievement Division (STAD) terhadap kemampuan penalaran matematis siswa. Penelitian ini menggunakan metode quasi experimental dengan desain matching-only posttest-only control group, yang dilaksanakan di salah satu SMA Negeri di Yogyakarta. Instrument yang digunakan adalah instrument tes yang telah valid dalam bentuk soal uraian. Hasil penelitian menunjukkan bahwa terdapat perbedaan yang signifikan pada kemampuan penalaran matematis antara siswa yang memperoleh pembelajaran dengan model Guided Inquiry dengan siswa yang memperoleh pembelajaran dengan model STAD. Selanjutnya, hasil penilaian rata-rata kemampuan penalaran matematis siswa yang memperoleh model pembelajaran guided inquiry lebih tinggi dibandingkan dengan siswa yang memperoleh model pembelajaran STAD.
\end{abstract}

Kata kunci: Guided Inquiry; STAD; Penalaran Matematis

\begin{abstract}
This study aims to determine differences of mathematical reasoning skills between students who obtain mathematics learning using Guided Inquiry model and Student Teams Achievements Division (STAD) model. This research method used is a quasi-experiment with matching only posttest only control group which implemented in one of the Senior High School in Yogyakarta. The instrument used is a valid test instrument namely posttest with descriptive evaluation. The result of this research showed that there is a difference of mathematical reasoning skills between students who obtain mathematics learning using guided inquiry model and students who obtain mathematics learning using STAD model. Furthermore, the average of mathematical reasoning skills between students who obtain mathematics learning
\end{abstract}

\footnotetext{
${ }^{1}$ Universitas Ahmad Dahlan, Yogyakarta, Indonesia, rully.indra@mpmat.uad.ac.id
} 
using guided inquiry model is higher than students who obtain mathematics learning using STAD model.

Keywords: Guided Inquiry; STAD; Mathematical Reasoning

\section{A. Pendahuluan}

Penalaran matematis adalah cara berpikir matematis siswa untuk menentukan benar atau salah dari sebuah pernyataan serta membangun suatu pernyataan matematika yang baru (Anisah, Zulkardi, \& Darmawijoyo, 2013; MZ, Risnawati, Kurniati, \& Prahmana, 2017). Sejalan dengan itu, penalaran matematis juga dapat didefinisikan sebagai kemampuan siswa dalam menarik kesimpulan berdasarkan sumber yang relevan dan pernyataan yang telah dibuktikan kebenarannya (Lestari, Prahmana, \& Wiyanti, 2016). Oleh karena itu, kemampuan penalaran matematis diartikan sebagai cara berpikir matematis siswa untuk menentukan kesimpulan, berdasarkan sumber yang relevan atau aturan yang telah dibuktikan kebenarannya.

Kemampuan penalaran matematis diperlukan sebagai kemampuan dasar yang digunakan untuk membangun pengetahuan matematika siswa (Burais, Ikhsan, \& Duskri, 2016; Widodo, Purnami, \& Prahmana, 2017). Salah satu tujuan dari dilaksanakannya kegiatan pembelajaran matematika adalah untuk meningkatkan kemampuan penalaran matematis siswa (Triastuti, Asikin, \& Wijayanti, 2014). Sejalan dengan itu, Wibowo (2017) menyatakan bahwa pentingnya kemampuan penalaran matematis disebabkan karena mampu meningkatkan kemampuan siswa dalam menemukan pola, generalisasi, dan evaluasi dari suatu permasalahan matematika. Selanjutnya, kemampuan penalaran matematis juga harus dimiliki oleh siswa pada tingkat sekolah menengah (Permana \& Sumarmo, 2007). Dalam hal ini, kemampuan penalaran matematis merupakan kemampuan yang sangat penting digunakan saat belajar matematika bagi siswa pada tingkat sekolah menengah.

Beberapa penelitian menunjukan bahwa kemampuan penalaran matematis siswa masih cenderung rendah (Permana \& Sumarmo, 2007; Amelia, 2015; Lestari, Prahmana, \& Wiyanti, 2016). Selanjutnya Kemampuan penalaran matematis dapat berpengaruh pada hasil belajar 
siswa (Roesdiana, 2016). Selain itu, pada umumnya guru hanya memberikan soal matematika yang berhubungan dengan pemahaman konsep saja tanpa memperhatikan aspek penalaran dan komunikasi (Emilya, Darmawijoyo, dan Putri, 2010; Ramdani, 2012). Sejalan dengan itu, salah satu penyebab dari rendahnya hasil belajar matematika siswa adalah guru memberikan skor yang besar pada soal penalaran sedangkan siswa lemah pada kemampuan penalaran matematis (Utami, Mukhni, \& Jazwinarti, 2014). Oleh sebab itu, peneliti mengidentifikasi bahwa kemampuan penalaran matematis siswa masih tergolong rendah karena proses pembelajaran yang dirancang oleh guru belum mencakup semua aspek yang harus dikuasai oleh siswa yaitu aspek pemahaman konsep, penalaran dan komunikasi, serta pemecahan masalah.

Penalaran induktif dan deduktif merupakan upaya yang dapat dilakukan untuk meningkatkan kemampuan penalaran matematis siswa (Bani, 2011). Selanjutnya, Sardin (2015) menyatakan bahwa penalaran merupakan proses berpikir dalam penarikan kesimpulan dengan cara menghubungkan fakta yang ada dikehidupan sehari-hari. Salah satu model pembelajaran yang sesuai dengan penalaran deduktif dan induktif atau menghubungkan fakta di kehidupan sehari-hari untuk memperoleh suatu kesimpulan yang umum adalah model pembelajaran guided inquiry.

Guided inquiry adalah model pembelajaran yang dapat membuat siswa memahami, memaknai, dan membangun pengetahuan baru (Yumiati \& Noviyanti, 2017). Selanjutnya, Amelia (2015) menyatakan bahwa pada kegiatan pembelajaran guided inquiry guru hanya membimbing dan mengarahkan siswa untuk menemukan suatu konsep, sehingga siswa dapat lebih memahami konsep tersebut, yang berakibat pada peningkatan kemampuan penalaran matematis siswa.

Selain guided inquiry, aktivitas pembelajaran dengan model pembelajaran STAD dapat meningkatkan kemampuan penalaran dan komunikasi matematis siswa (Muharom, 2014). Sejalan dengan itu, Nasution (2016) menyatakan bahwa STAD adalah model pembelajaran yang mendorong siswa untuk berperan aktif dalam proses pembelajaran melalui kerjasama antar siswa dengan cara membentuk kelompok dalam mempelajari suatu materi. Model pembelajaran STAD adalah model pembelajaran yang dapat menciptakan interaksi saling memotivasi dan kerjasama antar siswa pada saat kegiatan pembelajaran sehingga 
menghasilkan hasil belajar yang maksimal (Alfiliansi, Ismaimuza, \& Rochaminah, 2014).

Berdasarkan permasalahan di atas, peneliti tertarik untuk mengetahui perbedaan kemampuan penalaran matematis antara kelompok siswa yang memperoleh model pembelajaran guided inquiry dengan siswa yang memperoleh model pembelajaran STAD. Selanjutnya, peneliti ingin melihat perbedaan pengaruh dari implementasi kedua model pembelajaran tersebut.

\section{B. Metode Penelitian}

Penelitian ini merupakan penelitian kuantitatif dengan metode quasiexperimental dengan matching-only posttest-only control group design (Fraenkle \& Wallen, 2008), seperti disajikan pada Tabel 1.

Tabel 1. Desain Penelitian

\begin{tabular}{|c|c|c|c|}
\hline Kelompok & Subjek & Perlakuan & Tes akhir \\
\hline Eksperimen & $\mathrm{M}$ & $\mathrm{X}$ & $\mathrm{O}$ \\
\hline Kontrol & $\mathrm{M}$ & $\mathrm{C}$ & $\mathrm{O}$ \\
\hline
\end{tabular}

Keterangan:

M: Subjek penelitian

C: STAD

$\mathrm{X}$ : Guided Inquiry

O: Tes tertulis

Penelitian dilaksanakan di SMA Negeri 1 Jetis Bantul pada semester 1 tahun ajaran 2017/2018. Subjek penelitian adalah siswa kelas X MIPA 1 dan X MIPA 4. Teknik sampling yang digunakan untuk mendapatkan kelompok eksperimen maupun kelompok kontrol dipilih secara purposive atas pertimbangan kondisi, waktu, dan kemampuan siswa diantara kedua kelas tersebut. Variabel bebas dalam penelitian ini adalah model pembelajaran Guided Inquiry dan STAD, sedangkan variabel terikatnya adalah kemampuan penalaran matematis siswa.

Instrumen yang digunakan untuk mengukur kemampuan penalaran matematis siswa adalah tes tertulis dalam bentuk soal uraian yang terdiri dari 1 soal mudah, 1 soal sedang, dan 1 soal sulit. Soal nomor 1 mencari himpunan penyelesaian dari persamaan eksponensial $\frac{2^{3 x^{2}-6 x-7}}{36}=6^{x^{2}-6 x-9}$ merupakan soal kategori mudah karena siswa dapat menarik kesimpulan 
cukup dengan mengelompokkan bilangan eksponen yang sejenis kemudian menghitung akar dari pangkat persamaan eksponen tersebut.

Soal nomor 2 mencari himpunan penyelesaian dari persamaan eksponensial $\left(x^{2}-4 x+3\right)^{x-6}=\left(x^{2}-4 x+3\right)^{3 x+4}$ merupakan soal dengan kategori sedang karena siswa dapat menyelesaikannya berdasarkan sifatsifat persamaan eksponen yang telah dipelajarinya. Selanjutnya pada salah satu sifat eksponen untuk bentuk persamaan eksponen soal nomor 2, untuk $h(x)=1$ terdapat persamaan kuadrat yang tidak dapat dicari akar-akarnya secara langsung sehingga siswa dituntut untuk dapat mengingat dan mengaplikasikan rumus abc yang pernah dipelajari saat duduk dibangku SMP.

Soal nomor 3 juga mencari himpunan penyelesaian dari persamaan eksponensial $\left(3 x^{2}+7 x-3\right)^{x^{3}-16 x}=\left(2 x^{2}+10 x-5\right)^{x^{3}-16 x}$ yang merupakan soal dengan kategori sulit karena pada soal ini siswa harus dapat menemukan akar-akar dari persamaan polinomial berderajat 3 yang belum familiar bagi siswa. Selain itu, untuk soal nomor 1 sampai 3 pada tahap penarikan kesimpulan akhir siswa tidak dapat menarik kesimpulan secara langsung karena harus disesuaikan dengan aturan-aturan yang berlaku, sehingga siswa memerlukan kemampuan penalaran matematis untuk dapat menyimpulkan soal-soal tersebut. Sub pokok bahasan yang diujikan adalah eksponen. Uji validitas instrumen dilakukan secara walk through dengan guru pamong.

Perlakuan untuk kelas X MIPA 1 adalah pembelajaran matematika dengan Guided Inquiry sebagai kelas eksperimen dan untuk kelas X MIPA 4 adalah pembelajaran matematika dengan STAD sebagai kelas kontrol. Hasil data tes akhir, dibuatkan tabel dan dianalisis menggunakan statistik deskriptif dan uji independent t-test untuk mengetahui perbedaan pengaruh model pembelajaran kelas eksperimen dengan kelas kontrol terhadap kemampuan penalaran matematis siswa. Sebelum uji independent t-test, terlebih dahulu melakukan uji normalitas dan uji homogenitas. Uji normalitas dilakukan melalui One-Sample KolmogorovSmirnov Test sedangkan uji homogenitas dilakukan melalui uji independent t-test. 


\section{Temuan dan Pembahasan}

Guided inquiry adalah salah satu model pembelajaran yang dalam aktivitas pembelajarannya memposisikan guru sebagai fasilitator atau guru memberikan contoh-contoh yang kontekstual sesuai dengan materi yang sedang dibahas serta memandu siswa untuk memahami suatu konsep (Karim \& Maulida, 2014). Selanjutnya Jufri (2013) menyatakan bahwa langkah-langkah guided inquiry meliputi: 1) mengidentifikasi masalah; 2) mengembangkan tujuan atau hipotesis yang bersifat tentative; 3) mengumpulkan data dan menguji jawaban tentatif; 4) menginterpretasi data; 5) mengembangkan kesimpulan tentatif atau generalisasi; dan 6) menguji, menerapkan, dan merevisi kesimpulan. Oleh karena itu, pada aktivitas pembelajaran guided inquiry guru tidak diperbolehkan untuk langsung memberikan konsep, sifat, maupun jawaban mengenai suatu materi yang sedang dibahas.

Penerapan model pembelajaran guided inquiry menciptakan siswa sebagai pelaku utama dalam aktivitas pembelajaran, hal ini disebut juga dengan istilah student center learning. Oleh karena itu, pembelajaran matematika dengan menerapkan model pembelajaran guided inquiry merupakan pembelajaran yang bermakna dan siswa aktif dalam proses pembelajaran, karena siswa tidak hanya duduk, diam, mendengarkan penjelasan guru, kemudian mengerjakan soal latihan. Hal tersebut sejalan dengan kurikulum pendidikan 2013 yang berlaku saat ini menekankan siswa untuk berperan aktif dalam proses pembelajaran. Aktivitas proses pembelajaran dengan penerapan model pembelajaran guided inquiry dapat dilihat pada Gambar 1.

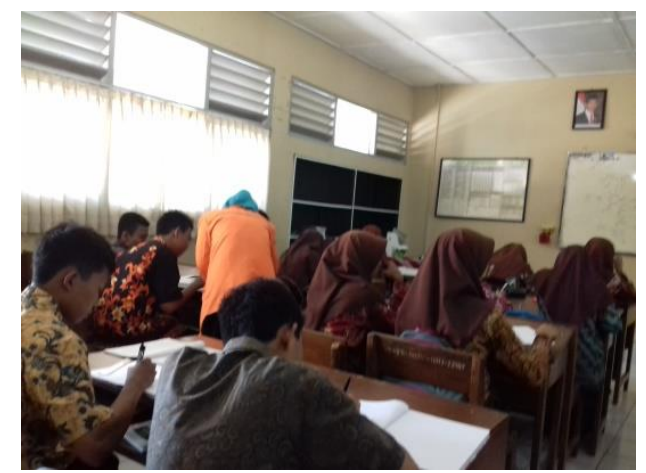

Gambar 1. Aktivitas pembelajaran dikelas eksperimen 
Berdasarkan Gambar 1. terlihat jelas bahwa aktivitas proses pembelajaran matematika di kelas yang menerapkan model pembelajaran guided inquiry berlangsung kondusif. Selain itu, siswa secara mandiri berusaha sesuai kemampuannya untuk menyelesaikan permasalahan yang diberikan oleh guru. Sejalan dengan itu, guru berkeliling kelas untuk melihat bagaimana cara siswa dalam menyelesaikan permasalahan tersebut serta segera membimbing siswa yang mengalami kesulitan. Siswa yang mengalami kesulitan hanya dibimbing oleh guru secara perlahan dan dengan penjelasan yang sederhana untuk dapat menyelesaikan permasalahan yang dihadapi sehingga siswa dapat lebih mudah menalar dengan apa yang dimaksudkan oleh permasalahan tersebut.

Selanjutnya secara bertahap guru memberikan soal matematika kepada siswa mulai dari tingkat soal yang mudah hingga soal hasil pengembangan dari konsep dasar materi eksponen. Hal ini dilakukan agar siswa dapat melatih kemampuan berpikir matematisnya dalam menyelesaikan soal yang sulit, sehingga secara tidak langsung dapat meningkatkan kemampuan penalaran matematis siswa.

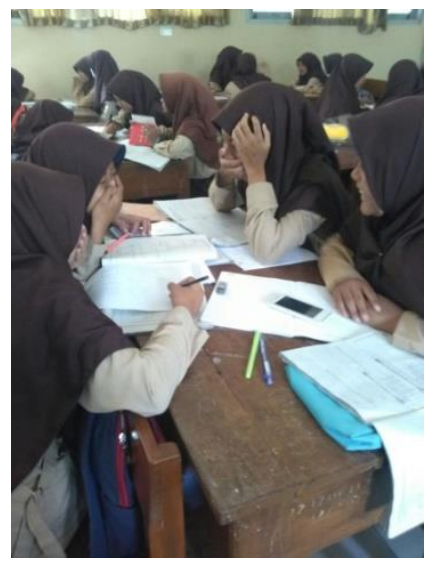

Gambar 2. Aktivitas pembelajaran di kelas kontrol

Langkah-langkah model pembelajaran STAD, yaitu: 1) guru menyampaikan materi; 2) siswa dikelompokkan secara heterogen berdasarkan kemampuan matematisnya; 3) diskusi kelompok; dan 4) kuis 
secara individu sebagai nilai individu dan kelompok (Sugianto, Armanto, \& Harahap, 2014). Sejalan dengan itu, pada aktivitas pembelajaran model STAD guru membagi siswa ke dalam beberapa kelompok yang heterogen sehingga siswa dapat mengingkatkan kemampuan penalaran dan komunikasi matematisnya. Aktivitas proses pembelajaran dengan penerapan model pembelajaran STAD dapat dilihat pada Gambar 2.

Gambar 2 menunjukan bahwa aktivitas pembelajaran didalam kelas yang menerapkan model pembelajaran STAD semua siswa mengelompok sesuai dengan kelompoknya. Kelompok tersebut merupakan kelompok heterogen yang setiap kelompok harus terdapat siswa yang memiliki kemampuan yang tinggi.

Pengelompokkan siswa secara heterogen dimaksudkan agar siswa yang memiliki kemampuan matematika tinggi dapat membantu siswa yang memiliki kemampuan matematika sedang maupun siswa yang memiliki kemampuan matematika rendah. Hal ini dianggap lebih efektif karena biasanya siswa lebih berani untuk bertanya kepada temannya dari pada ke guru mengenai materi pembelajaran. Selain itu, siswa juga dapat melatih kemampuan kerjasama dengan anggota kelompoknya dalam menyelesaikan permasalahan yang diberikan oleh guru.

Posisi guru pada aktivitas pembelajaran dengan model pembelajaran STAD juga sebagai fasilitator ilmu pengetahuan bagi siswanya. Guru berkeliling kelas untuk melihat kerjasama antar anggota di masingmasing kelompok. Jika siswa yang memiliki kemampuan matematika tinggi tidak dapat menjelaskan materi maupun penyelesaian permasalahan matematika dengan baik kepada anggota kelompoknya, maka tugas guru adalah menjelaskan materi yang sedang dibahas secara garis besarnya saja kepada kelompok tersebut. Kemudian siswa siswa yang memiliki kemampuan matematika tinggi dapat melanjutkan penjelasan guru sebelumnya kepada anggota kelompoknya. Sehingga dalam kelompok tersebut siswa dapat melatih kemampuan penalaran dan komunikasi matematisnya.

Instrumen penilaian yang digunakan dalam penelitian ini adalah tes tertulis akhir (posttest) yang berbentuk soal uraian dan terdiri dari 3 soal. Soal-soal tersebut memiliki taraf kesulitan yang berbeda-beda, yaitu soal nomor 1 soal mengenai konsep dasar, soal nomor 2 mengenai sifat-sifat eksponen, dan soal nomor 3 adalah soal pengembangan. 




Gambar 3. Salah satu hasil jawaban siswa

Kemampuan penalaran matematis adalah kemampuan berpikir matematis siswa dalam menarik kesimpulan berdasarkan pengelompokkan bilangan eksponen sejenis, aplikasi rumus abc, dan sifat-sifat persamaan eksponensial yang berlaku. Berdasarkan Gambar 3, terlihat bahwa siswa mengerjakan soal nomor 3 dengan baik, karena siswa tersebut dapat menyelesaikan permasalahan dengan 2 sifat sesuai aturan yang diberlakukan.

Pada sifat persamaan eksponensial kedua untuk soal nomor 3 siswa dipaksa untuk dapat menentukan bagaimana cara memfaktorkan fungsi eksponensial dengan pangkat persamaan polinomial pangkat 3 yang belum familiar bagi siswa, karena soal-soal yang ada pada modul 
pegangan siswa hanya membahas mengenai fungsi eksponensial dengan pangkat persamaan kuadrat. Selain itu, untuk soal nomor 1 sampai 3 pada tahap penarikkan kesimpulan akhir siswa juga dituntut untuk dapat mengingat dan memahami aturan-aturan yang berlaku. Sehingga siswa harus dapat memilih himpunan penyelesaian yang tepat untuk persamaan eksponensial yang diberikan.

Selanjutnya pada soal nomor 2 dan 3 siswa dituntut untuk dapat menyelesaikan fungsi eksponensial dengan persamaan kuadrat yang tidak dapat difaktorkan secara langsung melalui trial and error. Melainkan siswa harus dapat mengingat kembali materi sebelumnya saat masih duduk di bangku SMP mengenai penemuan akar dari suatu persamaan kuadrat dengan rumus abc. Terdapat banyak siswa yang masih salah dalam mengaplikasikan rumus abc tersebut, sehingga berimbas pada hasil akhir yang didapatkan.

Data yang diperoleh dalam penelitian terhadap siswa kelas eksperimen dan kelas kontrol dianalisis dengan teknik statistik deskriptif. Perolehan rata-rata hasil tes akhir untuk seluruh indikator soal dari kelas yang memperoleh pembelajaran matematika dengan guided inquiry dan kelas yang memperoleh pembelajaran matematika dengan STAD dapat dilihat pada Tabel 2.

Tabel 2. Rata-rata hasil tes akhir

\begin{tabular}{|l|c|c|c|c|}
\hline \multicolumn{1}{|c|}{ Kelas } & $\mathrm{N}$ & Mean & $\begin{array}{c}\text { Std. } \\
\text { deviation }\end{array}$ & $\begin{array}{c}\text { S.E } \\
\text { Mean }\end{array}$ \\
\hline $\begin{array}{l}\text { Pembelajaran } \\
\text { menggunakan guided } \\
\text { Inquiry }\end{array}$ & 32 & 79.13 & 13.08 & 2.31 \\
\hline $\begin{array}{l}\text { Pembelajaran } \\
\text { menggunakan STAD }\end{array}$ & 32 & 62.03 & 24.72 & 4.37 \\
\hline
\end{tabular}

Rata-rata hasil tes akhir (posttest) pada kelas yang menggunakan pembelajaran matematika dengan metode guided inquiry adalah 79.13, sedangkan pada kelas yang menggunakan pembelajaran matematika dengan STAD adalah 62.03 berdasarkan data pada Tabel 2. Oleh karena itu, rata-rata hasil tes akhir kelas yang menggunakan pembelajaran dengan guided inquiry lebih tinggi dari kelas yang menggunakan pembelajaran matematika dengan STAD. 
Hasil analisis menggunakan statistik parametrik dengan uji independent $t$-test ditunjukan pada Tabel 5. Sebelum melakukan uji parametrik, dilakukan uji normalitas dan homogenitas terlebih dahulu. Hasil uji normalitas dan homogenitas menunjukan bahwa kelas eksperimen dan kelas kontrol berdistribusi normal dan tidak homogen. Hasil uji normalitas dengan One-Sample Kolmogorov-Smirnov Test disajikan pada Tabel 3.

Tabel 3. Hasil Hasil uji normalitas dengan One-Sample KolmogorovSmirnov Test

\begin{tabular}{|l|c|}
\hline & Asymp (Sig. (2 tailed)) \\
\hline Kelas guided inquiry & 0.432 \\
\hline Kelas STAD & 0.143 \\
\hline
\end{tabular}

Berdasarkan Tabel 3, dapat disimpulkan bahwa untuk data kelas guided inquiry dan kelas STAD $\mathrm{H}_{0}$ diterima karena $0.432>0.05$ dan $0.143>0.05$, sehingga data kelas guided inquiry dan kelas STAD berdistribusi normal.

Hasil uji homogenitas dengan uji independent $t$-test disajikan pada Tabel 4.

Tabel 4. Hasil analisis statistik parametrik dengan uji independent t-test

\begin{tabular}{|l|c|}
\hline & $\begin{array}{c}\text { Levene's Test for Equality of Variances } \\
\text { (Sig.) }\end{array}$ \\
\hline Equal variances assumes & $0.00 \ldots$ \\
\hline Equal variances not assumes & $0.00 \ldots$ \\
\hline
\end{tabular}

Berdasarkan Tabel 4, dapat disimpulkan bahwa data kelas guided inquiry dan kelas $S T A D \mathrm{H}_{0}$ ditolak karena $0.00 \ldots<0.05$, sehingga data kelas guided inquiry dan kelas STAD tidak homogeny sehingga untuk melihat hasil uji independent $t$-test dapat dilihat pada Equal variances not assumes.

Hasil analisis statistik parametrik dengan uji independent t-test disajikan pada Tabel 5 .

Tabel 5. Hasil analisis statistik parametrik dengan uji independent $t$-test

\begin{tabular}{|l|c|}
\hline & $\begin{array}{c}\text { t-test for Equality of Means } \\
\text { (Sig. (2 tailed)) }\end{array}$ \\
\hline Equal variances assumes & 0.001 \\
\hline Equal variances not assumes & 0.001 \\
\hline
\end{tabular}


Perbedaan nilai rata-rata antara kelas yang menggunakan pembelajaran dengan guided inquiry dan kelas yang menggunakan pembelajaran STAD dianalisis dengan menggunakan uji independent $t$-test. Nilai probabilitas yang diperoleh (Sig. 2 tailed) bernilai di bawah 0.05 yaitu 0.001 , maka $\mathrm{H}_{0}$ ditolak, seperti tampak pada Tabel 5. Hal ini berarti bahwa terdapat perbedaan yang signifikan antara kelompok siswa yang menggunakan pembelajaran dengan Guided Inquiry dan kelas yang menggunakan pembelajaran dengan STAD. Selanjutnya, Tabel 2 menunjukan bahwa kemampuan penalaran matematis siswa pada kelas yang menggunakan pembelajaran dengan Guided Inquiry lebih tinggi dibandingkan dengan siswa pada kelas yang menggunakan pembelajaran dengan STAD.

Pembelajaran matematika dengan menggunakan model guided inquiry sangat membantu siswa dalam menalar suatu konsep, karena guru bertugas sebagai pembimbing siswa pada saat proses penemuan konsep secara individu sehingga setiap siswa memiliki kesempatan yang sama untuk dapat memahami suatu konsep. Di sisi lain, pembelajaran matematika dengan menggunakan model STAD guru menyampaikan materi kemudian siswa berdiskusi dengan anggota kelompoknya untuk mengerjakan lembar aktivitas siswa yang diberikan oleh guru, sehingga siswa kurang memahami konsep yang diberikan oleh guru. Kemampuan penalaran matematis siswa yang baik akan lebih memudahkan siswa untuk lebih memahami suatu permasalahan matematika yang rumit. Hal ini sejalan dengan penelitian Burais, Ikhsan dan Duskri (2016) yang menyatakan bahwa salah satu aspek yang mempengaruhi peningkatan hasil belajar siswa adalah peningkatan kemampuan penalaran matematis siswa.

Berdasarkan hasil penelitian Ridhwan (2011) tentang studi komparasi hasil belajar menggunakan model pembelajaran guided inquiry dan model pembelajaran STAD menunjukan bahwa penerapan model pembelajaran guided inquiry lebih baik untuk meningkatkan hasil belajar siswa dari pada model pembelajaran STAD. Hasil penelitian ini tidak bertentangan dengan penelitian sebelumnya (Ridhwan, 2011). Hasil penelitian ini menunjukan bahwa penerapan model pembelajaran guided inquiry dapat membantu siswa dalam menalar konsep matematika. Selain itu, kegiatan pembelajaran di dalam kelas berpusat pada siswa sedangkan guru hanya sebaga fasilitator ilmu sehingga menciptakan pembelajaran yang 
bermakna dan siswa lebih mudah memahami materi-materi lanjutan atau pengembangan yang sesuai dengan materi yang diajarkan.

\section{Simpulan}

Hasil penelitian ini menunjukan bahwa terdapat perbedaan kemampuan penalaran matematis yang signifikan antara kelas eksperimen dengan kelas kontrol. Kelompok siswa yang memperoleh pembelajaran menggunakan metode guided inquiry memiliki nilai ratarata kemampuan penalaran yang lebih tinggi dibandingkan kelompok siswa yang memperoleh pembelajaran menggunakan metode STAD. Hal ini sejalan dengan penelitian sebelumnya (Burais, Ikhsan \& Duskri 2016; Ridhwan, 2011) sehingga memberikan penegasan tentang pengaruh model guided inquiry terhadap kemampuan penalaran matematis siswa.

\section{Ucapan Terima Kasih}

Peneliti mengucapkan banyak terimakasih kepada pihak sekolah SMA Negeri 1 Jetis Bantul Yogyakarta yang telah mengizinkan peneliti untuk melakukan penelitian di kelas X MIPA 1 dan X MIPA 4 tahun ajaran 2017/2018. Selain itu, terimakasih juga kepada guru pamong yang telah bersedia memvalidasi instrumen tes tertulis untuk penelitian ini.

\section{Daftar Pustaka}

Alfiliansi, Ismaimuza, D., \& Rochaminah, S. (2014). Penerapan model pembelajaran kooperatif tipe STAD berbantuan blok aljabar untuk meningkatkan hasil belajar siswa pada penjumlahan dan pengurangan bentuk aljabar di kelas VIII SMP Negeri 12 Palu. Jurnal Elektronik Pendidikan Matematika Tadulako, 2(2), 127-135.

Amelia, R. (2015). Pencapaian kemampuan penalaran matematis siswa SMP dengan menggunakan metode pembelajaran inkuiri terbimbing. $P 2 M$ STKIP Siliwangi, 2(1), 98-105.

Anisah, A., Zulkardi, Z., \& Darmawijoyo, D. (2013). Pengembangan soal matematika model PISA pada konten quantity untuk mengukur kemampuan penalaran matematis siswa sekolah menengah pertama. Jurnal Pendidikan Matematika, 5(1), 1-15. 
Bani, A. (2011). Meningkatkan kemampuan pemahaman dan penalaran matematik siswa sekolah menengah pertama melalui pembelajaran penemuan terbimbing, SPS UPI, Bandung. Jurnal Penelitian Pendidikan, Edisi Khusus (1), 12-20.

Burais, L., Ikhsan, M., \& Duskri, M. (2016). Peningkatan kemampuan penalaran matematis siswa melalui model Discovery Learning. Jurnal Didaktik Matematika, 3(1), 77-86.

Emilya, D., Darmawijoyo, D., \& Putri, R. I. I. (2013). Pengembangan soal-soal open-ended materi lingkaran untuk meningkatkan penalaran matematika siswa kelas VIII SMP Negeri 1o Palembang. Jurnal Pendidikan Matematika, $4(2), 8-18$.

Fraenkle, J.R., \& Wallen, N.E. (2009). How to design and evaluate research in education ( $7^{\text {th }}$ edition). New York: McGraw-Hill.

Jufri, A. W. (2013). Belajar dan pembelajaran sains. Bandung: Pustaka Reka Cipta.

Karim \& Maulida, T. (2014). Pengaruh model penemuan terbimbing terhadap pemahaman konsep matematika siswa kelas VIII SMP. EDU-MAT Jurnal Pendidikan Matematika, 2(1),62-69.

Lestari, I., Prahmana, R. C. I., \& Wiyanti, W. (2016). Peningkatan kemampuan penalaran matematis siswa menggunakan pendekatan pendidikan matematika realistik. Jurnal Inovasi Pendidikan Dasar, 1(2), 45-50.

Muharom, T. (2014). Pengaruh pembelajaran dengan model kooperatif tipe Student Teams Achievement Division (STAD) terhadap kemampuan penalaran dan komunikasi matematik peserta didik di SMK Negeri Manonjaya Kabupaten Tasikmalaya. Jurnal Pendidikan dan Keguruan, 1(1), 1-11.

MZ, Z.A., Risnawati, Kurniati, A., \& Prahmana, R.C.I. (2017). Adversity quotient in mathematics learning (Quantitative study on students boarding school in Pekanbaru). International Journal on Emerging Mathematics Education, 1(2), 169-176.

Nasution, U. S. (2016). Perbedaan kemampuan pemecahan masalah matematika siswa yang diajar dengan menggunakan model pembelajaran STAD dan NHT. Jurnal Mathematics Pedagogic, 7(1), 51-57.

Permana, Y., \& Sumarmo, U. (2007). Mengembangkan kemampuan penalaran dan koneksi matematik siswa SMA melalui pembelajaran berbasis masalah. Educationist, 1(2), 116-123.

Ramdani, Y. (2012). Pengembangan instrumen dan bahan ajar untuk meningkatkan kemampuan komunikasi, penalaran, dan koneksi matematis dalam konsep integral. Jurnal Penelitian Pendidikan, 13(1), 4452.

Ridhwan, A. F. (2011). Studi komparasi hasil belajar fisika menggunakan model pembelajaran guided inquiry dan STAD (Student Teams Achievement Division) pada siswa kelas VIII SMPN 1 Batealit Jepara materi 
pokok gaya tahun pelajaran 2011/2012. Skripsi. Tidak dipublikasikan. Semarang: Universitas Islam Negeri (UIN) Walisongo.

Roesdiana, L. (2016). Pembelajaran dengan pendekatan metaphorical thinking untuk mengembangkan kemampuan komunikasi dan penalaran matematis siswa. Judika (Jurnal Pendidikan Unsika), 4(2) 169-184.

Sardin. (2015). Perbandingan keefektifan pembelajaran Gl dan problem solving ditinjau dari prestasi belajar peluang, kemampuan penalaran, dan sikap siswa terhadap matematika. PYTHAGORAS: Jurnal Pendidikan Matematika, 10(2), 189-200.

Sugianto, Armanto, D., \& Harahap, M. B. (2014). Perbendaan penerapan model pembelajaran kooperatif tipe Jigsaw dan STAD ditinjau dari kemampuan penalaran dan komunikasi matematis siswa SMA. Jurnal Didaktik Matematika, 1(1), 96-128.

Triastuti, R., Asikin, M., \& Wijayanti, K. (2014). Keefektifan model CIRC berbasis Joyfull Learning terhadap kemampuan penalaran matematis siswa SMP. Unnes Journal of Mathematics Education, 3(2), 132-137.

Utami, N. P., Mukhni., \& Jazwinarti. (2014). Kemampuan penalaran matematis siswa Kelas XI IPA SMAN 2 Painan melalui penerapan pembelajaran Think Pair Square. Jurnal Pendidikan Matematika, 3(1), 712.

Wibowo, A. (2017). Pengaruh pendekatan pembelajaran matematika realistik dan saintifik terhadap prestasi belajar, kemampuan penalaran matematis dan minat belajar. Jurnal Riset Pendidikan Matematika, 4(1), 1-10.

Widodo, S. A., Purnami, A. S., \& Prahmana, R. C. I. (2017). Team accelerated instruction, initials and problem-solves ability in junior high school. International Journal on Emerging Mathematics Education, 1(2), 193-204.

Yumiati \& Noviyanti, M. (2017). Abilities of reasoning and mathematics representation on guided inquiry learning. Journal of Education and Learning (EduLearn), 11(3), 283-290. 